Research Papers, part of a Special Feature on Bird Conservation in the Boreal Forest: Is there a Case for Resilience?

\title{
Local, Short-term Effects of Forest Harvesting on Breeding Waterfowl and Common Loon in Forest-Dominated Landscapes of Quebec
}

\section{Effets locaux et à court terme de la récolte forestière sur la sauvagine et le Plongeon huard en période de nidification dans le Québec forestier}

\author{
$\underline{\text { Louis-Vincent Lemelin }}^{1,2}, \underline{\text { Louis Imbeau }}^{1}$, Marcel Darveau $^{2,3}$, and Daniel Bordage $^{4}$
}

\begin{abstract}
Northern forests are major breeding habitats for several waterfowl and other waterbird species. In Quebec, as in many other areas within the boreal region, clear-cut logging is an important human activity, and it is likely to affect ground- and cavity-nesting species differently. We used Black Duck Joint Venture/Canadian Wildlife Service aerial survey data, together with Quebec digital forest maps, to investigate local, i.e., within $2 \mathrm{~km}$ of clear-cut areas, short-term $(\sim 4 \mathrm{yr})$ effects of forest harvesting on waterfowl and Common Loon. Our predictions were that clear-cut logging would not affect ground nesters, but would negatively affect pair settling patterns in cavity nesters through nesting habitat disturbance. Our study spanned a $540,000-\mathrm{km}^{2}$ territory in which we considered over 30,000 ha of clear-cut areas that were dispersed into 42 different locations. We controlled for interannual variation in population size by comparing the pre- and post-harvest percentages of potentially hospitable nesting cover disturbed by timber harvesting within a 1-km radius of indicated breeding pairs. Our results suggest that timber harvesting positively influenced local populations of Canada Goose and American Green-winged Teal. No other ground-nesting species showed a significant response. For the cavity-nesting guild and species, we detected no local, shortterm effect of clear-cutting. This result was unexpected because many previous studies of nest-box provisioning reported increased breeding pair densities, indicating that availability of natural holes may limit cavity-nesting duck populations. Moreover, because cavity-nesting ducks are considered among the most vulnerable bird species to forest management, our results are consistent with the hypothesis that boreal bird populations exhibit some resilience to disturbance. This conclusion follows from a study in landscapes where forests were mostly first-growth. It is not evident that it will remain valid following subsequent clear-cutting episodes and long-term forestry.
\end{abstract}

RÉSUMÉ. Les forêts nordiques sont des habitats essentiels pour plusieurs espèces de sauvagine et d'autres oiseaux aquatiques. Au Québec comme dans beaucoup d'autres territoires forestiers boréaux, l'exploitation forestière est une activité humaine importante susceptible d'influencer les espèces de sauvagine nichant au sol différemment de celles nichant en cavité. À partir des données de l'inventaire aérien du Plan conjoint sur le Canard noir-Service canadien de la faune et des cartes écoforestières numériques du Québec, nous avons étudié les effets locaux (à moins de $2 \mathrm{~km}$ des aires de coupe) et à court terme (environ 4 ans) de la récolte forestière sur les populations de sauvagine et de Plongeon huard en période de nidification. Nos prédictions étaient que la récolte n'influencerait pas le patron de répartition des couples d'espèces nichant au sol, mais affecterait négativement celui des nicheurs en cavité par une altération de l'habitat de nidification. Notre étude s'est étendue sur un territoire de $540000 \mathrm{~km}^{2}$, dans lequel nous avons considéré plus de 30000 ha d'aires de coupe réparties en 42 localités différentes. Nous avons tenu compte des variations interannuelles des niveaux de population en comparant les pourcentages d'habitat de nidification potentiel

${ }^{1}$ Université du Québec en Abitibi-Témiscamingue, ${ }^{2}$ Ducks Unlimited Canada, ${ }^{3}$ Laval University, ${ }^{4}$ Canadian Wildlife Service

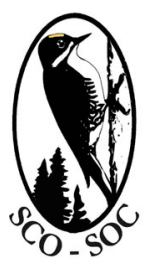

Sponsored by the Society of Canadian Ornithologists and Bird Studies Canada

Parrainée par la Société des ornithologistes du Canada et Études d'oiseaux Canada

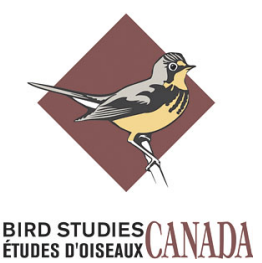


récolté à l'intérieur d'un rayon de $1 \mathrm{~km}$ des localisations d'équivalents-couples nicheurs, avant et après coupe forestière. Nos résultats indiquent que la coupe forestière a influencé positivement les populations locales de Bernache du Canada et de Sarcelle d'hiver. Aucune autre espèce nichant au sol n'a montré de réponse significative à la coupe totale. Pour la guilde et les espèces nichant en cavité, nous n'avons détecté aucun effet significatif local et à court terme des coupes totales. Ce résultat est inattendu puisque plusieurs expériences précédentes d'ajout de nichoirs ont résulté en une augmentation de la densité de couples nicheurs, indiquant que les populations de canards nichant en cavité pourraient être limitées par la disponibilité de sites de nidification. De plus, puisque les canards nichant en cavité sont considérés comme les espèces d'oiseaux les plus vulnérables face aux activités d'aménagement forestier, nos résultats sont en accord avec l'hypothèse selon laquelle il existerait une certaine résilience des populations boréales d'oiseaux face aux perturbations. Cette conclusion découle d'une étude réalisée dans des paysages où les peuplements forestiers étaient principalement de première venue; rien n'indique qu'elle demeurera valide après des épisodes répétés de coupe à blanc et d'autres interventions forestières.

Key Words: boreal; breeding; cavity nesters; clear-cut; forest harvesting; ground nesters; nest site; population size; Quebec; waterfowl.

\section{INTRODUCTION}

More than 20 Anatidae and 1 Gaviidae species breed in forest-dominated landscapes of the eastern Canadian boreal forest, with annual numbers averaging over 350,000 breeding pairs in Quebec alone. Moreover, Quebec forests constitute the core of the breeding range of the American Black Duck (Anas rubripes) (Longcore et al. 2000), as well as partial ranges of 14 other ground-nesting and 6 cavity-nesting species. This region may contain the core of the breeding area of Barrow's Goldeneye (Bucephala islandica) in eastern North America (Robert et al. 2000), a threatened population. Because many of the waterfowl populations that breed in Quebec are hunted throughout the Atlantic flyway, biological knowledge regarding the factors responsible for variation in population size is of prime interest for both hunting and conservation purposes (NAWMP Plan Committee 2004).

Quality of breeding habitat may be seen as one of the main factors affecting waterfowl populations (Conroy et al. 2002), and forest harvesting has been regularly pointed out as having a potential influence on breeding habitats (e.g., Rusch et al. 1989, Robert et al. 1999). Impacts of timber harvesting on forest landscapes are long lasting, as several decades may be necessary for initial tree cover and large trees to grow again. Effects of forest harvesting on breeding waterfowl and Common Loon (Gavia immer) population sizes or dynamics have never been specifically addressed within the eastern Canadian boreal forest and have also received little attention in other forested ecosystems.

During the breeding season, nesting can be seen as the most "terrestrial" part in the life of aquatic birds and thus the most likely to be affected by forest management activities. One striking difference in nesting characteristics among waterfowl species is that some build their nests on the ground while others rely on existing tree cavities.

Ground nesters display some variability in nest site preferences, notably in terms of distance from water and vegetation cover. Although many species usually build their nests within a few meters from the edge of water, e.g., Ring-necked Duck (Aythya collaris) (Mendall 1958), Common Loon (McIntyre 1983), and Lesser Scaup (A. affinis) (Corcoran 2005), others frequently select nest sites at greater distances from water, e.g., American Black Duck (Stotts and Davis 1960, Ringelman et al. 1982), Mallard (Anas platyrhynchos) (Gilmer et al. 1975), American Widgeon (Anas americana) (Mowbray 1999), American Green-winged Teal (Anas crecca carolinensis) (Johnson 1995), and Surf Scoter (Melanitta perspicillata) (Savard et al. 1998). Even though preferences in vegetation physiognomy may vary among ground-nesting species and habitat types, species within this group generally seek the concealment of dense low cover for nest establishment (Bellrose 1976, McIntyre and Barr 1997). The only exception to this rule is Canada Goose (Branta canadensis), which prefers nest sites 
with good visibility (Mowbray et al. 2002). In forested habitats, there is no evidence that availability of nest sites is a limiting factor for ground-nesting populations of waterbirds. However, more comprehensive knowledge on the overall effects of forest harvesting on breeding habitats is still needed, as other mechanisms may be involved in determining reproductive success.

Cavity-nesting ducks use large secondary cavities (Darveau and Desrochers 2001), which are provided by large woodpeckers or which are created in physically damaged trees (Pöysä and Pöysä 2002). Six of these species are known to breed in Quebec (Gauthier and Aubry 1995). The Wood Duck (Aix sponsa) nests in hollow branches or trunks of deciduous trees or, less frequently, in Pileated Woodpecker (Dryocopus pileatus) holes (Godfrey 1967, Prince 1968, Hepp and Bellrose 1992). Common Goldeneye (Bucephala clangula) usually nests in cavities and readily uses chimney-type cavities (Prince 1968), although other microsites may be used (Eadie et al. 1995, Bordage 1996). Barrow's Goldeneye has only be recently confirmed to nest in the eastern forests of North America (Robert et al. 2000) and its nest site preferences remain unknown. It has been associated in western Canada with Pileated Woodpecker holes (Evans et al. 2002), but this latter species is scarce in Barrow's eastern breeding grounds. The needs of Bufflehead (Bucephala albeola) have also been studied mostly in western Canada, where it is associated with Northern Flicker (Colaptes auratus) holes (Gauthier 1993). Although it is present all across the boreal biome (Alvo 1995), Common Merganser (Mergus merganser) has received relatively little attention compared to other waterfowl species. It is generally considered to nest in tree cavities and readily uses nest-boxes (Cramp and Simmons 1977), but the Common Merganser also uses other types of sites, such as holes in shore banks or bushes (Godfrey 1967, Bellrose 1976). The scientific literature is also scarce on the nest site preferences of the Hooded Merganser (Lophodytes cucullatus), but it is known to nest in tree cavities (Bellrose 1976, Dugger et al. 1994, Maisonneuve et al. 2002). Overall, although these species regularly use bucket-type structures instead of typical enclosed, lateral tree holes (Prince 1968, Maisonneuve et al. 2002), nesting in natural forested habitats rarely occurs in non-tree cavities (Bellrose 1976).

Clear-cutting is considered harmful to breeding populations for which cavity density is a limiting resource (Newton 1994). In waterfowl, many nest- box experiments have shown an increase in breeding pair densities relative to pre-treatment (Haramis and Thompson 1985, Savard 1988, but see Gauthier and Smith 1987), suggesting that nest sites could limit population sizes in some cases. However, increases in breeding pairs were not always sustainable (Johnson 1967), proportional to density of nest-box additions (Eriksson 1982, Fredga and Dow 1984), or accompanied by a proportional increase in broods or fledged birds (Pöysä and Pöysä 2002, Savard and Robert 2007), suggesting that other resources such as space or food may play a role in the determination of population sizes. Also, cavity characteristics other than density, such as accessibility (Prince 1968, Peterson and Gauthier 1985), location (Pierre et al. 2001, Evans et al. 2002), or their physical attributes (Robb and Bookhout 1995), may be important for the assessment of forest logging effects on cavitynesting ducks. On the whole, factors that limit populations of cavity-nesting ducks appear to be the result of a region-specific balance among many factors (Pöysä and Pöysä 2002), but previous research suggests that negative impacts of forest harvesting are more likely to occur than positive ones (Imbeau et al. 2001).

In this paper we used Black Duck Joint Venture (BDJV)/Canadian Wildlife Service (CWS) aerial survey data, together with digital forest maps, to investigate the local, short-term effects of timber harvesting on waterfowl and Common Loon in forest-dominated landscapes of Quebec. Effects were measured by the percentage of nesting habitat disturbed by timber harvest within a $1-\mathrm{km}$ radius of breeding pair locations, in a pre- vs. post-harvest comparison. We report evidence for possible positive effects in a few ground-nesting species and limited effects in cavity-nesting species for the period and the area under study. This study provides an evaluation of the stability and resilience of waterfowl and Common Loon to timber harvesting, with stability being defined as the probability of all populations persisting (Walker 1995), and resilience being the capacity of populations to absorb disturbance (Walker et al. 2004).

\section{METHODS}

\section{Study area}

Our study was carried out in forest-dominated landscapes of Quebec, located south of $51^{\circ} 15^{\prime} \mathrm{N}$, but excluding the St. Lawrence and Lake St. Jean 
lowlands and the southernmost part of the Appalachians (Fig. 1). This 540,000-km² area roughly corresponds to the public forest lands in Quebec, and extends northward from temperate deciduous forest to the boreal coniferous forest zone. Open water and wetlands with tree cover less than $25 \%$ cover nearly $18 \%$ of the total area (Ménard et al. 2006). Beavers (Castor canadensis) are ubiquitous within the study area, although their abundance is higher in the western part of the region (Lafond and Pilon 2004).

Human activities in Quebec's forests are mostly directed toward extraction of natural resources. Timber production was the most visible activity over the duration of our study with more than 3000 $\mathrm{km}^{2}$ clear-cut annually, being equivalent to $0.51 \%$ of total public forest lands and to $1.0 \%$ of the productive, accessible public lands allocated for timber harvest (MRNQ 2002). Forest harvesting has substantially affected the forest over the last decades, inducing stand rejuvenation and simplification of forest composition and structure (Crête and Marzell 2006). The timber industry has also severely altered the hydrographical network by maintaining numerous water reservoirs and dams for timber floating, which was prevalent until the end of the 1980s. Other sources of human alteration include mining, hydroelectric power generation, acid rain, and recreational resorts (Lee 2004).

\section{Waterfowl surveys}

We obtained waterfowl data from the Black Duck Joint Venture and Canadian Wildlife Service (BDJV/CWS) aerial survey of Quebec. This survey was implemented in 1990 and was designed to produce accurate population size estimates of American Black Duck and other waterfowl species in forest-dominated landscapes. From 1990 to 1992 , 82 systematically distributed square plots $(10 \times 10$ $\mathrm{km})$ were surveyed. Because of budgetary restrictions, the number of plots was dropped to 43 in 1993-1994, and to 35 in 1995. Since 1996, plot size was reduced to $5 \times 5 \mathrm{~km}$ and the number of plots increased to 156; half of the plots are surveyed once annually in a rotating scheme (Bordage et al. 2003). All survey years from 1990 to 2003 were considered for potential use in the analyses. Surveys were done using a helicopter (Bell 206L with bubble sidewindows) that flew over every body of water, watercourse, and wetland within the plot. Flight altitude was $15-50 \mathrm{~m}$ above ground and speed varied from $60-100 \mathrm{~km} / \mathrm{h}$. All waterfowl seen by three observers were noted on topographic maps (scale 1:50,000) with a 100-m precision and were later transferred to a geographic information system. Surveys were done during egg laying or at the beginning of the incubation period of the American Black Duck, on average from 6-30 May. Breeding pair observations, which were used in analyses, were determined following indicated breeding pair (IBP) criteria of the BDJV in eastern Canada (Bordage et al. 2003). For all duck species and the Common Loon that were detected from 1990 to 2003 in the BDJV/CWS aerial surveys, $82 \%$ of the birds detected positively entered the indicated breeding pair (IBP) criteria and $71 \%$ of the birds were observed in groups of two birds or less, indicating good survey timing not only for the American Black Duck but also for most other species. As examples, direct breeding evidence within our study area suggests that BDJV/CWS surveys were also conducted during the egg-laying or incubation period of the Common Goldeneye and Hooded Merganser (Sénéchal 2003). For Canada Goose, which breeds extensively in the northern third of Quebec (Malecki and Trost 1990), regular observations of active nests and eggs in 46 plots also substantiated breeding evidence and the adequacy of BDJV/CWS survey timing (Lemelin et al. 2004).

Detectability biases are important characteristics of surveys that can be categorized into visibility bias and availability bias. In these surveys, visibility bias, i.e., birds potentially visible from the helicopter, but missed by the observers, was estimated with sight-resighting data, a technique that is analogous to mark-recapture, in which front and rear observers are independent. For several sources of variability, including habitat type, group size, date, and distance from the helicopter, visibility bias was considered negligible for most species tested (N. Plante and D. Bordage, Canadian Wildlife Service, unpublished report). Availability bias, i.e., for concealed birds not visible from the helicopter was not assessed, but was partly controlled for through the indicated breeding pair calculations. Overall, it is unlikely that forest harvesting could have modified detectability rates because shorelines were surveyed from the water side, and individuals that were detected were usually flushed from open water. In addition, a mandatory 20-m wide forested buffer strip separated all wetlands and permanent streams from clear-cuts and the same experienced observers were in place throughout most of the survey period. 


\section{Timber harvesting and nesting habitat information}

Temporal evolution of landscapes with regard to timber harvesting was reconstructed using digitized ecoforestry maps of the Quebec Ministry of Natural Resources and Fauna. Maps had information on years and boundaries of clear-cuts that occurred before the 2003 bird survey. Maps were queried to locate blocks harvested in the plots and conducted between two waterfowl-survey years. Cutting operations that spanned more than one year in a single plot were considered as a single clear-cut for pre/post comparisons. Clear-cut areas located outside the survey plots up to $2 \mathrm{~km}$ were included in the analyses.

Timber harvest regulations during the sample period generally prescribed logging of all merchantable stems over $9.0 \mathrm{~cm}$ in diameter at breast height. Clear-cut blocks, i.e., contiguous cut areas, exceeding 150 ha were normally not authorized, and had to be separated by 100-m wide forest strips (60$\mathrm{m}$ strips for 100-ha blocks). Forested buffer strips 20-m wide were mandatory around lakes, rivers, wetlands, and all permanent streams (Gouvernement du Québec 1988, 1996). During the study period, first-growth stands occupied the northern third of the study areas, whereas second-growth forests that had been harvested once or twice grew on the southern part (Crête and Marzell 2006). Clear-cut blocks that were used in our analyses totaled 33,886 ha and were spread across 42 survey plots (Fig.1). Thirty-two of the plots were $25 \mathrm{~km}^{2}$ and had a median cut area of 263 ha (range: 3 to 1463 ha), and 10 were $100 \mathrm{~km}^{2}$ with a median cut area of $447 \mathrm{ha}$ (range: 13 to 2676 ha). Cut hectare distribution followed a negative exponential function, with $25 \%$ were in cut blocks $<33$ ha, $50 \%$ in cut blocks $<60$ ha, and $75 \%$ in cut blocks < 114 ha. Eighteen percent of cut hectares were in cut areas exceeding 150 ha all in one block. Considering the total area located within the plots and no further than $2000 \mathrm{~m}$ away from the cut areas, $70 \%$ of the productive forests were originally mature stands (> $60 \mathrm{yr}$ of age) and $22 \%$ of the productive forest area has been clear-cut between pre- and post-treatment waterfowl surveys.

Nesting habitat information in uncut land patches was also extracted from the ecoforestry maps to assess potentially hospitable nesting areas for both ground and cavity nesters. Nesting habitat for ground-nesting species included forest stands of all ages, saturated open wetlands, shrub swamps, and rock barrens with less than $25 \%$ tree cover, whereas open water areas, dead flooded swamps, and areas with land uses more disruptive than timber production were excluded. Nesting habitat for cavity nesters, i.e., land patches likely to support cavity trees, only included forest stands of all ages (Courteau et al. 1997) and dead flooded swamps.

\section{Statistical analyses}

According to the BDJV/CWS aerial survey, waterfowl breeding population sizes varied during the 1990-2003 period (Fig 2). When analyzing effects of habitat changes on species, one has to account for coarser-scale temporal fluctuations in population sizes that are not caused by the treatment (Pierre and Paszkowski 2000). Since the survey plots were systematically separated by $45 \mathrm{~km}$ intervals and because they were not large enough to randomly select control sites, they were not appropriate for paired treatment/control samples. Hence, we compared survey data in each plot before and after harvest in a pre/post retroduction approach (Nichols 1991).

To measure the local, short-term effects of forest harvesting on breeding waterfowl and Common Loon, we measured the percentage of undisturbed nesting habitat within a $1-\mathrm{km}$ radius of each IBP location, considering the same cut areas for pre- and post-treatment years. The $1-\mathrm{km}$ radius (314-ha circle area) was chosen because it is in the same order of magnitude than known home-range sizes of waterfowl species in forest habitats (Ringelman et al. 1982, Kirby et al. 1985). Considering all IBP of a population within $2 \mathrm{~km}$ from clear-cut areas, the distribution of this percentage was expected to vary only if clear-cuts induced a biologically significant change to the breeding habitat of pairs, regardless of fluctuations in population size between years (Fig. 3). A negative difference indicated a lower undisturbed nesting habitat (higher $\%$ of clear-cut) after treatment than before, and vice-versa. We justify the inclusion of IBP until $2 \mathrm{~km}$ from clear-cuts for several reasons: (1) the buffered area beside clear-cuts had to be large enough to track potential change in distribution of pairs avoiding clear-cuts, which should include a greater proportion of undisturbed nesting habitat at the scale of their home range post treatment, (2) the buffered area also had to be restricted enough to ensure that IBP disturbed by harvest according to our selected radius were adequately represented in 
Fig. 1. The study area, a 540,000- $\mathrm{km}^{2}$ forest-dominated territory, with the $15625-\mathrm{km}^{2}$ square plots. Circular grey-shaded pictograms symbolize clear-cut density $(\%)$ in each plot calculated over the total area located within 1-km from any clear-cut area. Low values indicate small, scattered clear-cut areas whereas high values (max. 59\%) indicate large, clustered clear-cut areas.

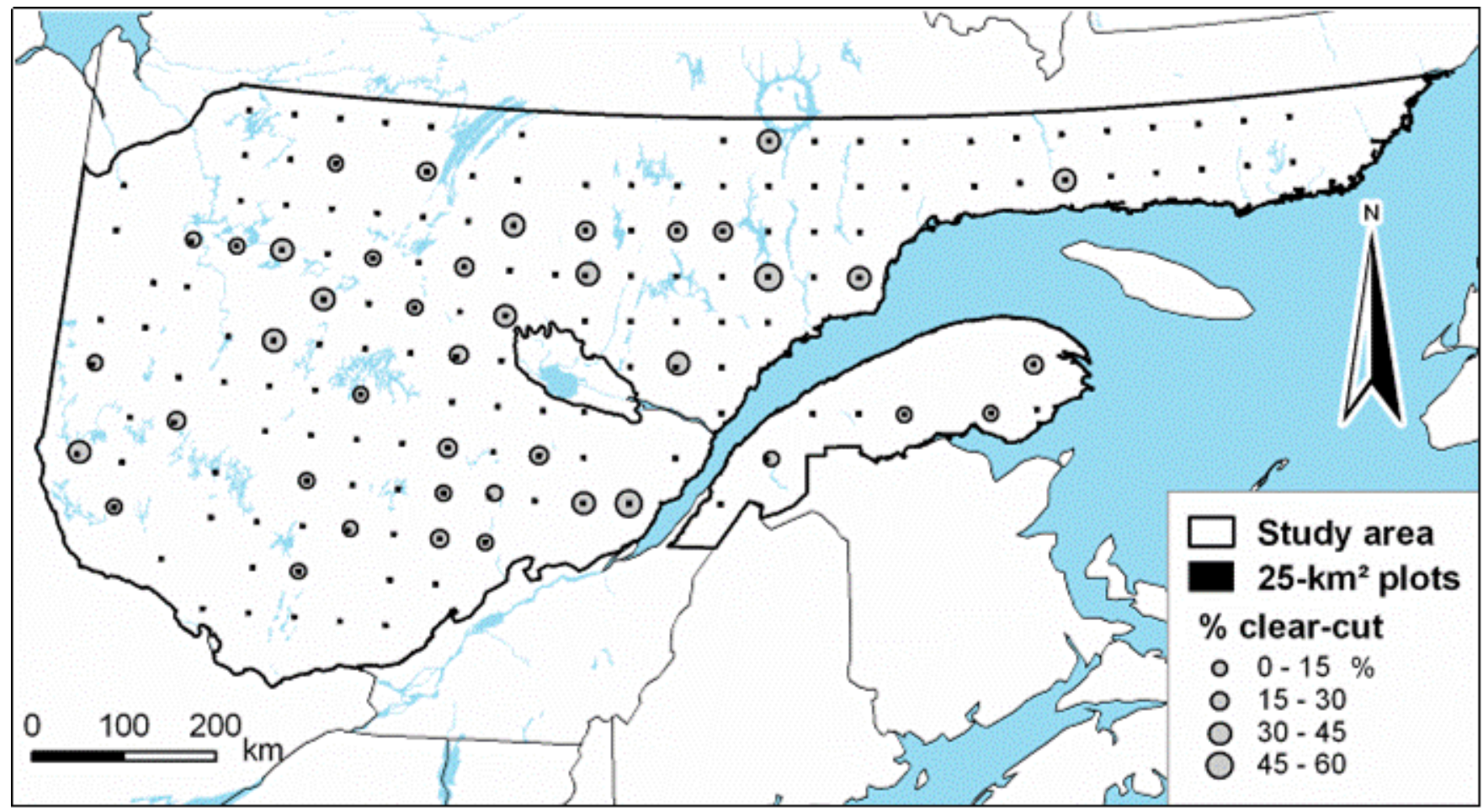

the pre-treatment sample. Furthermore, the $2 \mathrm{~km}$ distance was also chosen under the constraint of our minimal plot size $\left(25 \mathrm{~km}^{2}\right)$ : it was the threshold distance above which the number of logged plots still containing IBP data at such distant area would have dropped below 30 .

Due to low waterfowl density, which is generally less than $1.0 \mathrm{IBP} / \mathrm{km}^{2}$, plots and years were pooled. We used the maximum available number of waterfowl survey years per period and per plot as long as they were equal in pre-treatment and posttreatment periods. Thus, survey years occurring between two harvest years were excluded. For example, if in a given plot we had five available survey years before the treatment but only two afterwards, we used the last two years before and used the two years after. When the number of available survey years was smaller before than after, we kept the last years of the post-treatment period to allow maximum time for populations to adjust their local distributions following the habitat change. We tested for differences of undisturbed nesting habitat in pre- vs. post-harvest periods with the nonparametric Mann-Whitney $U$-test. This test was performed on all species total, on both ground and cavity nesters guilds, as well as on the nine most abundant species, i.e., Canada Goose, American Black Duck, Mallard, American Green-winged Teal, Ring-necked Duck, Common Loon, Common Goldeneye, Common Merganser, and Hooded Merganser. Tests were two-tailed and differences were considered significant at $P \leq 0.05$. All statistical tests were performed in SAS (Version 9.1, SAS Institute Inc. 2002). 
Fig. 2. Population trends of ground nesters and cavity nesters, including the seven most abundant species: American Black Duck, Ring-necked Duck, Common Goldeneye, Common Merganser, and Canada Goose, Common Loon, and American Greed-winged Teal. Population sizes are IBP for the whole study area: values extrapolated from survey plots to the whole $540,000-\mathrm{km}^{2}$ study area; left vertical axis, and IBP/100 km² (right vertical axis) for the 1990-2003 period. Population trends for all species surveyed are available in Bordage et al. (2003).

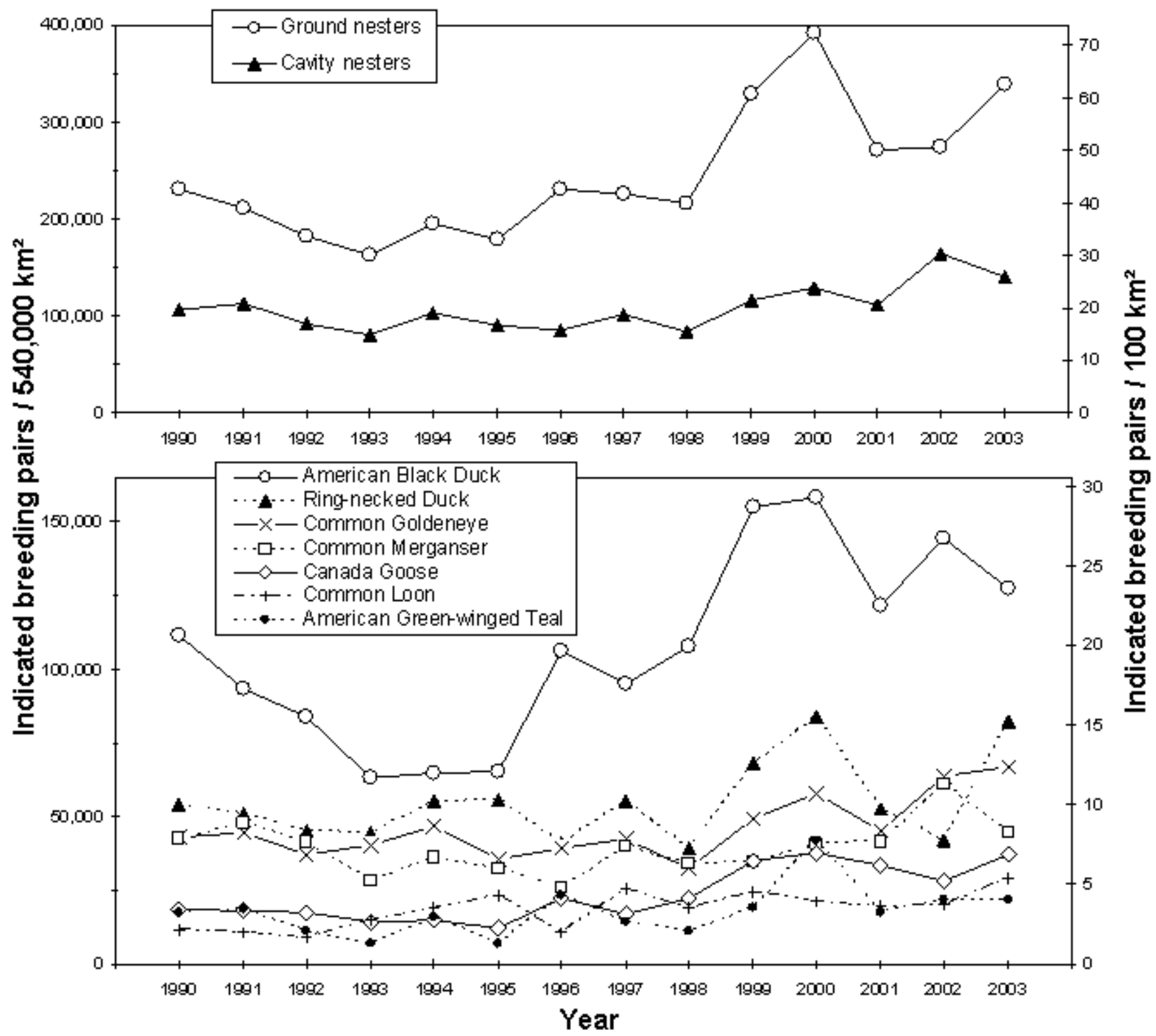


Fig. 3. Example of a harvested plot (partial) with all IBP locations of a single survey year, as well as an example of an IBP (black star) with its 1-km radius circle. For that particular IBP, the percentage of nesting habitat undisturbed by timber harvesting was $47 \%$ for ground-nesting species and $45 \%$ for cavity-nesting species (see Methods for details on definition of nesting habitat). Clear-cut areas used for these calculations are the same for pre- and post-harvest periods.

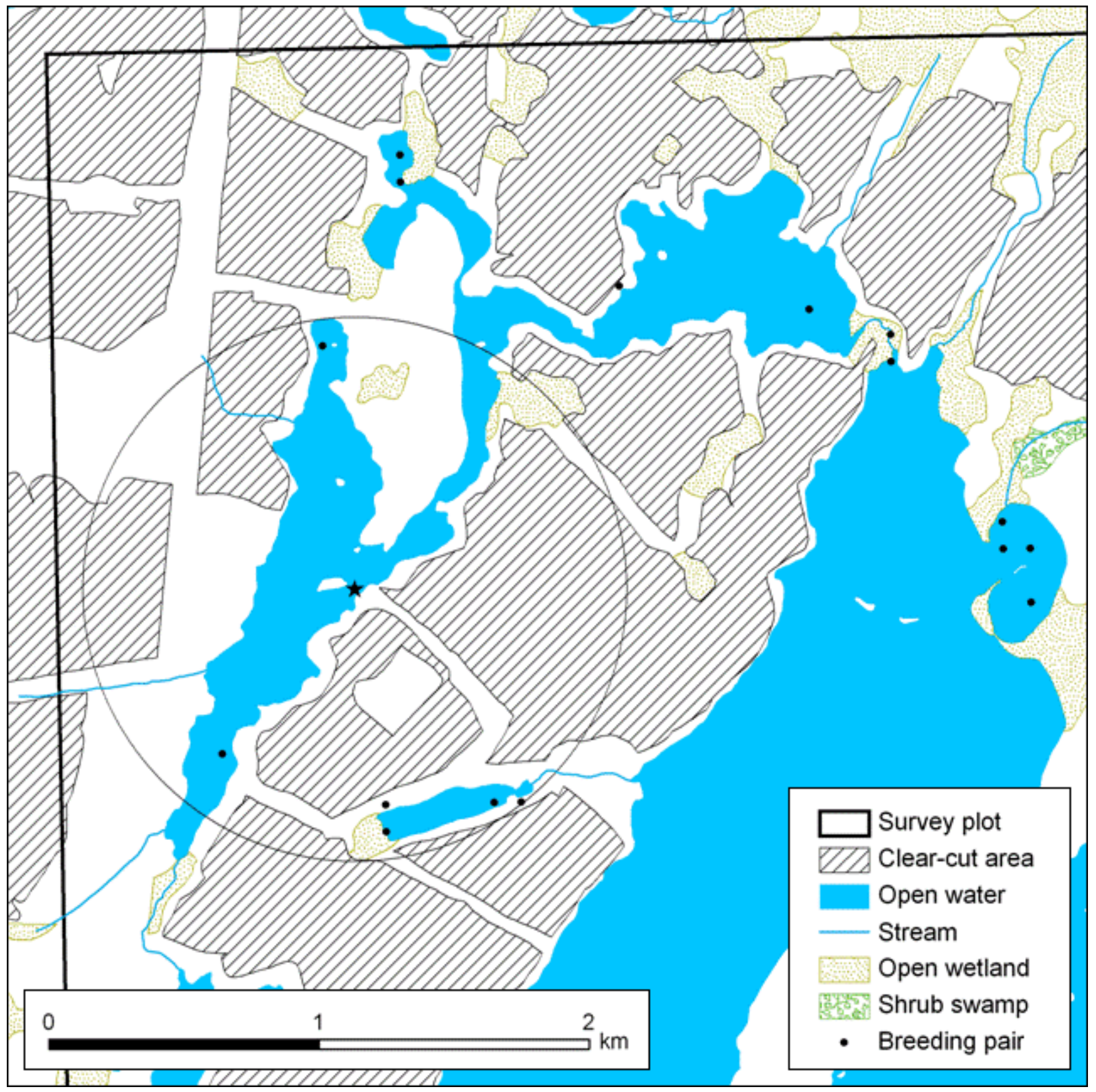




\section{RESULTS}

Waterfowl censuses allowed the detection and use of 2061 indicated breeding pair (IBP) for 18 species. Twelve species were ground nesters, arranged from most to least abundant as follows: American Black Duck, Ring-necked Duck, Canada Goose, Common Loon, American Green-winged Teal, Mallard, Surf Scoter, Black Scoter (Melanitta nigra), Lesser Scaup, Red-breasted Merganser (Mergus serrator), American Widgeon, and Blue-winged Teal (Anas discors.) The latter six species each had less than 20 IBP. There were six species of cavity-nesting ducks: Common Goldeneye, Common Merganser, Hooded Merganser, Bufflehead, Wood Duck, and Barrow's Goldeneye; each of the latter three had no more than 20 IBP.

The mean number $( \pm$ SD) of waterfowl survey years used per period for each plot and the average delay of the response measure, i.e., the time gap between harvest and post-harvest IBP surveys, were estimated to $2.5 \pm 1.4 \mathrm{yr}$ and $4.0 \pm 2.3 \mathrm{yr}$, respectively.

Canada Goose $(P=0.026)$ and American Greenwinged Teal $(P=0.024)$ were the only species to present a significant post-harvest decrease in percentage of undisturbed nesting habitat in their 1$\mathrm{km}$ surroundings (Table 1). The guild of ground nesters also showed a decrease $(P=0.031)$. For all other species and guilds tested, no statistically significant differences were detected. Raw data used in the analyses, in the form of cumulative distributions of counts and percentages, are graphically presented on Fig. 4 for ground nesters, Canada Goose, American Green-winged Teal, cavity nesters, and all species combined. Intensity of harvesting may be indicated by the percentage of nesting habitat that was subsequently disturbed by clear-cut for the 5th IBP percentile during the preharvest reference period. This value was $37 \%$ and $35 \%$ for ground nesters and cavity nesters, respectively (Fig. 4).

\section{DISCUSSION}

\section{Ground nesters}

The relationship between ground-nesting waterfowl and logging has received little attention (Rusch et al. 1989). Currently, there is no evidence that availability of nest sites is a limiting factor for ground-nesting populations of aquatic birds in forested habitats. Our study brings evidence that breeding pairs of ground-nesting species are not negatively affected, in their settling pattern, by timber harvesting of a part of their 1-km surrounding area in the short term. This agrees with our initial prediction and would indicate that forest landscapes, even following actual clear-cut logging, offer more suitable nest sites than those required by ground nesters. We also found that breeding pair numbers within $2-\mathrm{km}$ of clear-cut areas increased in all species after timber harvest (Table 1). However, because of the aerial survey design constraints, we could not rigorously separate these local increases from the broadscale, general increases observed in most species (Fig. 2).

Mechanisms other than nest site shortage may be involved in determining local population sizes and are susceptible to be influenced by logging. Such dynamics may be involved in the positive responses that we observed after clear-cutting for Canada Goose and American Green-winged Teal. In both species, more pairs were located within $2 \mathrm{~km}$ of clear-cut areas (Fig. 4), and those pairs had lower percentage of undisturbed nesting habitat in their 1$\mathrm{km}$ surroundings after clear-cutting (Table 1). While preference for open nesting habitat with good visibility in Canada Goose may explain part of the results, it does not apply to American Green-winged Teal, whose nests are relatively well concealed compared to other ground-nesting ducks (Johnson 1995). Because the breeding biology of American Green-winged Teal is poorly known (Paquette and Ankney 1996), and because we did not collect more data than that of the BDJV/CWS aerial survey, further studies are needed to better understand these results and validate their biological significance.

\section{Cavity nesters}

The role of nest site limitations in cavity-nesting ducks has mostly been studied through the provision of nest-boxes for Bucephala species in small areas (Fredga and Dow 1984, Gauthier and Smith 1987, Savard 1988, Pöysä and Pöysä 2002, Savard and Robert 2007). However, forest management can act as a natural-cavity removal agent and thus conclusions derived from nest-box provision studies might be difficult to link to our study.

We detected no significant local, short-term effect of forest harvesting on cavity-nesting ducks based on the pre- vs. post-harvest distributions of 
Table 1. Results of the nonparametric Mann-Whitney $U$-tests comparing pre- and post-harvest distributions of the percentage of nesting habitat left undisturbed by timber harvesting within a 1-km radius of indicated breeding pair (IBP) locations. Tests include all IBP located within $2 \mathrm{~km}$ of clear-cut areas. Median percentages of undisturbed nesting habitat and pre/post median differences are presented: a negative difference indicates a lower undisturbed nesting habitat (higher \% of clear-cut) after treatment than before, and vice-versa. Statistics are given for all individual species totaling over $30 \mathrm{IBP}$, for guilds of ground nesters and cavity nesters, and for all species combined.

\begin{tabular}{|c|c|c|c|c|c|c|}
\hline & Period & IBP numbers & $\begin{array}{c}\text { Median \% of } \\
\text { undisturbed nesting } \\
\text { habitat }\end{array}$ & $\begin{array}{l}\text { Pre/post } \\
\text { difference } \\
(\%)\end{array}$ & $\boldsymbol{Z}^{\dagger}$ & $P$ \\
\hline \multicolumn{7}{|l|}{ Ground nesters } \\
\hline \multirow[t]{2}{*}{ Canada Goose } & Pre- & 37 & 97.3 & -13.0 & -2.224 & 0.026 \\
\hline & Post- & 94 & 84.3 & & & \\
\hline \multirow[t]{2}{*}{ American Black Duck } & Pre- & 241 & 89.0 & -0.4 & -0.962 & 0.336 \\
\hline & Post- & 344 & 88.6 & & & \\
\hline \multirow[t]{2}{*}{ Mallard } & Pre- & 12 & 92.4 & 1.0 & 0.817 & 0.414 \\
\hline & Post- & 39 & 93.4 & & & \\
\hline \multirow[t]{2}{*}{ Green-winged Teal } & Pre- & 42 & 92.9 & -10.4 & -2.254 & 0.024 \\
\hline & Post- & 65 & 82.5 & & & \\
\hline \multirow[t]{2}{*}{ Ring-necked Duck } & Pre- & 149 & 93.1 & -2.3 & -1.092 & 0.275 \\
\hline & Post- & 154 & 90.7 & & & \\
\hline \multirow[t]{2}{*}{ Common Loon } & Pre- & 56 & 91.8 & 2.1 & 0.809 & 0.419 \\
\hline & Post- & 71 & 93.9 & & & \\
\hline \multirow[t]{2}{*}{ Total } & Pre- & 563 & 91.7 & -2.0 & -2.152 & 0.031 \\
\hline & Post- & 778 & 89.6 & & & \\
\hline \multicolumn{7}{|l|}{ Cavity nesters } \\
\hline \multirow[t]{2}{*}{ Common Goldeneye } & Pre- & 144 & 85.9 & -4.2 & -0.907 & 0.365 \\
\hline & Post- & 162 & 81.8 & & & \\
\hline \multirow[t]{2}{*}{ Common Merganser } & Pre- & 148 & 89.9 & 1.0 & -0.428 & 0.669 \\
\hline & Post- & 152 & 90.9 & & & \\
\hline \multirow[t]{2}{*}{ Hooded Merganser } & Pre- & 24 & 98.7 & -0.6 & 0.053 & 0.958 \\
\hline & Post- & 50 & 98.2 & & & \\
\hline
\end{tabular}




\begin{tabular}{|c|c|c|c|c|c|c|}
\hline \multirow[t]{2}{*}{ Total } & Pre- & 337 & 89.6 & 0.3 & -0.165 & 0.869 \\
\hline & Post- & 380 & 89.9 & & & \\
\hline \multirow[t]{2}{*}{ All species total } & Pre- & 901 & 91.3 & -1.6 & -1.618 & 0.106 \\
\hline & Post- & 1,160 & 89.7 & & & \\
\hline
\end{tabular}

percentages of undisturbed nesting habitat (Table 1). Our results were consistently nonsignificant for all species tested, despite differences in cavity characteristic preferences among species (Prince 1968, Bellrose 1976, Maisonneuve et al. 2002). Moreover, Common Goldeneye, Common Merganser, and Hooded Merganser had higher pair numbers after logging (Table 1), but again these increases could not be rigorously dissociated from coarserscale population trends over our study area. These slight IBP increases do support the conclusion that forest harvesting induced no negative local, shortterm effect on cavity-nesting ducks.

One way to analyze the relationship between cavities and cavity nesting ducks is to consider the following characteristics of cavities: density, detectability, and accessibility. If timber harvesting unavoidably lessens cavity density, then a number of cavities could remain after at least one episode of forest harvesting and consequently, they could become more easily detectable and accessible to ducks. This hypothesis is especially relevant for coniferous-dominated stands where deciduous trees remain unharvested (Courteau et al. 1997), but invariably it applies to cavity trees located near cutblock edges. Other potential effects of forest logging operating through nest sites include changes in predation rates (Pierre et al. 2001), the consequences of nest parasitism, and nest-site competition. On the whole, factors such as cavities can become limiting with shifts in the balance in relative density among available resources, such as open water, food, nest sites, competitors, and predators. The complexity of this equation coupled with our lack of fitness data precludes inferences regarding which biological processes could have operated. Based on these considerations and on the high degree of resemblance between our pre- and post-harvest counts and percentage curves (Fig. 4), a simple and reasonable explanation for our results lies in either (1) cavities having not been limiting; or (2) cavity resources having not been significantly depleted after what is likely the case in most of our study area, a first episode of forest harvesting. We also acknowledge that the level of clear-cutting in our study plots, i.e., approximately $22 \%$ of forest loss, despite its representativeness of the harvest operations conducted within our general study area, may yet be considered below a potential critical threshold (sensu Andrén 1994) of mature forest loss for cavity-nesting ducks.

\section{Waterbird life-cycle perspective}

In concert with nest site modifications, forestry operations could have influenced waterfowl population sizes in more subtle ways. Nutritional requirements of waterfowl species, which include various plant and animal foods (Bellrose 1976), have proved to be particularly influential during duckling and fledgling stages (Patterson 1976, Gunnarsson et al. 2004). In forested landscapes, animal foods could be considered as more vulnerable than plant foods to disturbances such as changes in water chemistry or in sediment runoffs. However, it has been demonstrated that the benthic macroinvertebrate communities of boreal lakes were little influenced by logging activities (Scrimgeour et al. 2000). Other effects associated with, but external to, forestry activities could include fish introductions into fishless lakes and disturbance caused by sport fishers in lakes only made accessible by resource extraction roads (Robert et al. 1999). 
Fig. 4. Indicated breeding pairs (IBP) cumulative numbers (left column) and percentages (right column) plotted against percentage of nesting habitat undisturbed by timber harvest for both pre- and post-harvest periods. For example, 92 indicated breeding pairs of ground nesters, representing $16 \%$ of all pairs detected within $2000 \mathrm{~m}$, had more than $60 \%$ of undisturbed nesting habitat for the pre-harvest period. These values changed to 141 IBP and $18 \%$, respectively, post-harvest. $P$-values are that of the MannWhitney $U$-tests. It is worth noting that in all cases, curves of IBP raw counts were higher post-harvest than pre-harvest, and post-harvest relative counts (\%) had a generally lower percentage of nesting habitat left undisturbed by timber harvesting than pre-harvest relative counts.

Counts
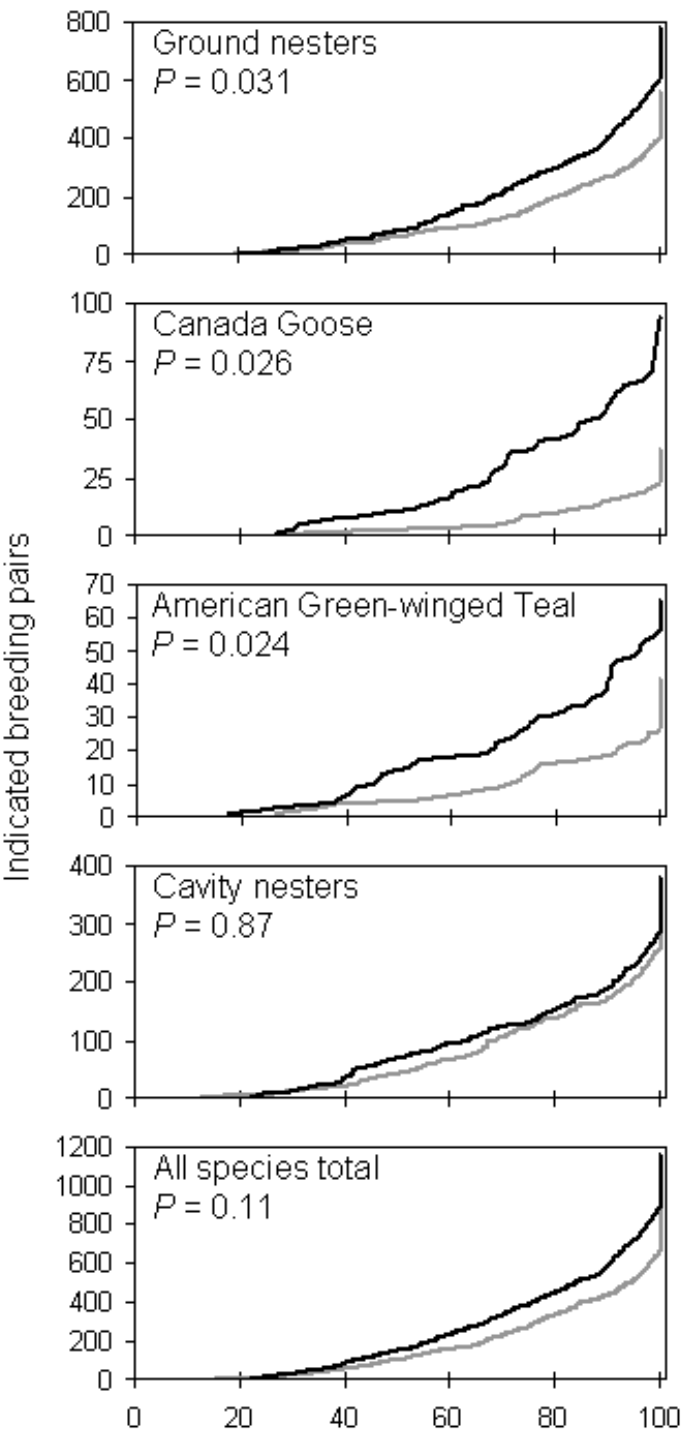
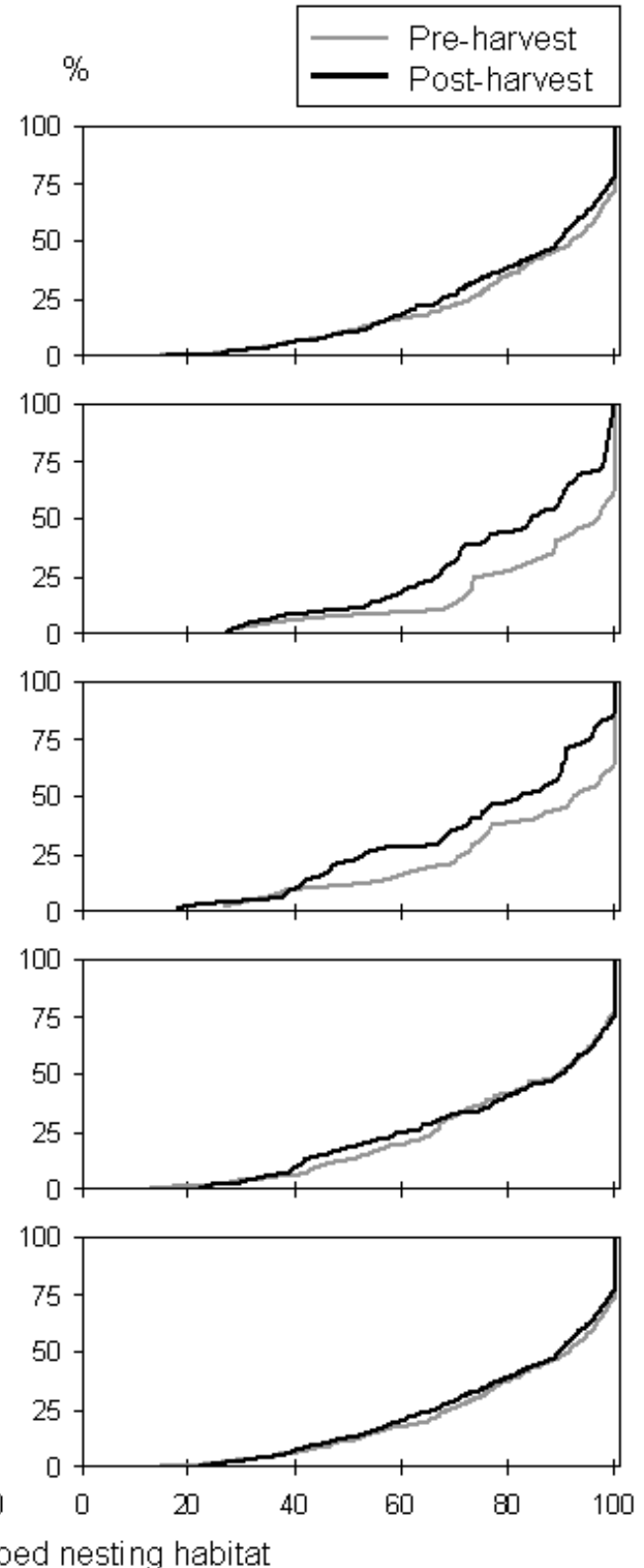


\section{CONCLUSION}

Our study provides a first approximation of the local, short-term effects of forest harvesting on waterfowl species and Common Loon. Our results suggest that these aquatic bird species might be resilient to major disturbances of the forest cover in their breeding grounds. This conclusion is in agreement with other studies on boreal terrestrial birds that have shown these species to be resilient to disturbances (Schmiegelow et al. 1997), and that their abundances and densities are highly variable (Niemi et al. 1998), perhaps as a result of the variability of the boreal environment itself (Pastor et al. 1998). Moreover, the ground-nesting bird species that we studied have a very large distribution range, and they are adapted to a wide variety of nesting covers and habitats (Baldassarre and Bolen 2006). Given that resilience to a disturbance could be predicted by the range of conditions across the distribution range of a species (Jiguet et al. 2006), ground-nesting waterfowl may on the one hand be even more resilient than other boreal bird species. On the other hand, because of their large body-size and their dependence of existing cavities and large trees, cavity-nesting ducks are considered among the bird species that are the most vulnerable to forest management (Imbeau et al. 2001). From our results, these species appeared stable and therefore resilient to timber harvesting in the short term, adding some support to the hypothesis of general resilience of boreal birds to disturbance.

Although we have reported limited impacts of forest harvesting, the next step could be to investigate the mechanisms involved in population regulation by directly assessing nest sites and fitness effects in harvested vs. unharvested landscapes. Our results also reflected what happened within $2 \mathrm{~km}$ of clearcuts in the study area and only over a short period ( $\sim 4$ years). These harvest treatments had to respect specific environmental regulations and were performed on specific stands that were often experiencing a first episode of severe clear-cutting (Crête and Marzell 2006). Results might be different with subsequent clear-cutting episodes and longterm forestry (Imbeau et al. 2001).

Responses to this article can be read online at: http://www.ace-eco.org/vol2/iss2/art10/responses/

\section{Acknowledgments:}

This project received financial support from the Black Duck Joint Venture, the Canadian Wildlife Service, Ducks Unlimited Canada, the Québec Ministry of Natural Resources and Wildlife, the Fondation de l'Université du Québec en AbitibiTémiscamingue, and the Canadian Boreal Initiative. L. V. Lemelin benefited from a Natural Sciences and Engineering Research Council of Canada graduate scholarship. We thank the observers and pilots who logged many hours in helicopters doing the surveys. We thank D. G. McAuley, S. Slattery, an anonymous reviewer, and the coeditors $F$. K. A. Schmiegelow and M. A. Villard for suggestions and careful review of the manuscript. We are also grateful to $A$. Desrochers, M. J. Mazerolle, C. Maisonneuve, and T. D. Nudds for stimulating discussions held about this study and to W. F. J. Parsons for his help with copy editing.

\section{LITERATURE CITED}

Andrén, H. 1994. Effects of habitat fragmentation on birds and mammals in landscapes with different proportions of suitable habitat: a review. Oikos 71:355-366.

Baldassarre, G. A., and E. G. Bolen. 2006. Waterfowl ecology and management. Second edition. Krieger, Malabar, Florida, USA.

Bellrose, F. C. 1976. Ducks, geese and swans of North America. Second edition. Stackpole Books, Harrisburg, Pennsylvania, USA.

Bordage, D. 1996. Common Goldeneye. Pages 328-331 in J. Gauthier and Y. Aubry, editors. The breeding birds of Québec: atlas of the breeding birds of southern Québec. Association québécoise des groupes d'ornithologues, Province of Quebec Society for the Protection of Birds, Canadian Wildlife Service, Environment Canada, Québec Region, Montréal, Québec, Canada.

Bordage, D., C. Lepage, and S. Orichefsky. 2003. 2003 Black Duck Joint Venture helicopter survey, Québec. Annual report. Canadian Wildlife Service, Québec Region, Environment Canada, Sainte-Foy, 
Québec, Canada. available online at: http://www.qc. ec.gc.ca/faune/faune/pdf/PCCN2003 EN.pdf.

Conroy, M. J., M. W. Miller, and J. E. Hines. 2002. Identification and synthetic modeling of factors affecting American Black Duck populations. Wildlife Monographs 150.

Corcoran, R. M. 2005. Lesser Scaup nesting ecology in relation to water chemistry and macroinvertebrates on the Yukon Flats, Alaska. Thesis. University of Wyoming, Laramie, Wyoming, USA.

Courteau, M., M. Darveau, and J. P. L. Savard. 1997. Effets des coupes forestières sur la disponibilité de sites de nidification pour le Garrot à ail d'or (Bucephala clangula) en sapinière boréale. Série de rapports techniques Number 270. Service Canadien de la Faune, région du Québec, Environnement Canada, Sainte-Foy, Québec, Canada.

Cramp, S., and K. E. L. Simmons, editors. 1977. The birds of the western Palearctic. Volume 1: Ostrich-Ducks. Oxford University Press, Oxford, UK.

Crête, M., and L. Marzell. 2006. évolution des forêts québécoises au regard des habitats fauniques: analyse des grandes tendances sur trois décennies. The Forestry Chronicle 82:368-382.

Darveau, M., and A. Desrochers. 2001. Le bois mort et la faune vertébrée: état des connaissances au Québec. Rapport DEF-0199. Ministère des Ressources naturelles du Québec, Direction de l'environnement forestier, Québec, Québec, Canada.

Dugger, B. D., K. M. Dugger, and L. H. Fredrickson. 1994. Hooded Merganser (Lophodytes cucullatus). In A. Poole and F. Gill, editors. The birds of North America, Number 98. The Academy of Natural Sciences, Philadelphia, Pennsylvania, and The American Ornithologists' Union, Washington, D.C., USA.

Eadie, J. M., M. L. Mallory, and H. G. Lumsden. 1995. Common Goldeneye (Bucephala clangula). In A. Poole and F. Gill, editors. The birds of North America, Number 170. The Academy of Natural Sciences, Philadelphia, Pennsylvania, and The American Ornithologists' Union, Washington, D.
C., USA.

Eriksson, M. O. G. 1982. Differences between old and newly established Goldeneye Bucephala clangula populations. Ornis Fennica 59:13-19.

Evans, M. R., D. B. Lank, W. S. Boyd, and F. Cooke. 2002. A comparison of the characteristics and fate of Barrow's Goldeneye and Bufflehead nests in nest boxes and natural cavities. The Condor 104:610-619.

Fredga, S., and H. Dow. 1984. Factors affecting the size of a local population of Goldeneye, Bucephala clangula (L.) breeding in Sweden. Viltrevy 13:225-255.

Gauthier, G. 1993. Bufflehead (Bucephala albeola). In A. Poole and F. Gill, editors. The birds of North America, Number 67. The Academy of Natural Sciences, Philadelphia, Pennsylvania, and The American Ornithologists' Union, Washington, D.C., USA.

Gauthier, G., and J. N. M. Smith. 1987. Territorial behaviour, nest-site availability, and breeding density in Buffleheads. The Journal of Animal Ecology 56:171-184.

Gauthier, J., and Y. Aubry, editors. 1995. Atlas des oiseaux nicheurs du Québec méridional. Service canadien de la faune, Association québécoise des groupes d'ornithologues et Société québécoise de protection des oiseaux, Montréal, Québec, Canada.

Gilmer, D. S., I. J. Ball, L. M. Cowardin, J. H. Riechmann, and J. R. Tester. 1975. Habitat use and home range of mallards breeding in Minnesota. Journal of Wildlife Management 39:781-789.

Godfrey, W. E. 1967. Les oiseaux du Canada. Musée national du Canada, Ottawa, Ontario, Canada.

Gouvernement du Québec. 1988. Règlement sur les normes d'intervention dans les forêts du domaine public. Gazette officielle du Québec 46:5527-5535.

Gouvernement du Québec. 1996. Règlement sur les normes d'intervention dans les forêts du domaine public. Gazette officielle du Québec 19:2750-2786.

Gunnarsson, G., J. Elmberg, K. Sjüberg, H. Pöysä, and P. Nummi. 2004. Why are there so many 
empty lakes? Food limits survival of mallard ducklings. Canadian Journal of Zoology 82:1698-1703.

Haramis, G. M., and D. Q. Thompson. 1985. Density-production characteristics of box-nesting Wood Ducks in a Northern Greentree impoundment. Journal of Wildlife Management 49:429-436.

Hepp, G. R., and F. C. Bellrose. 1992. Wood Duck (Aix sponsa). In A. Poole and F. Gill, editors. The birds of NorthAmerica, Number 169. The Academy of Natural Sciences, Philadelphia, Pennsylvania, and The American Ornithologists' Union, Washington, D.C. USA.

Imbeau, L., M. Münkkünen, and A. Desrochers. 2001. Long-term effects of forestry on birds of the eastern Canadian boreal forests: a comparison with Fennoscandia. Conservation Biology 15:1151-1162.

Jiguet, F., R. Julliard, T. O. Dehorter, S. E. Newson, and D. Couvet. 2006. Thermal range predicts bird population resilience to extreme high temperatures. Ecology Letters 9:1321-1330.

Johnson, K. 1995. Green-winged Teal (Anas crecca). In A. Poole and F. Gill, editors. The birds of North America, Number 193. The Academy of Natural Sciences, Philadelphia, Pennsylvania, and The American Ornithologists' Union, Washington, D.C., USA.

Johnson, L. L. 1967. The Common Goldeneye Duck and the role of nesting boxes in its management in north-central Minnesota. Journal of The Minnesota Academy of Science 34:110-113.

Kirby, R. E., J. H. Riechmann, and L. M. Cowardin. 1985. Home range and habitat use of forest-dwelling mallards in Minnesota. The Wilson Bulletin 97:215-219.

Lafond, R., and C. Pilon. 2004. Abondance du castor (Castor canadensis) au Québec: bilan d'un programme d'inventaire aérien. Le Naturaliste canadien 128:43-51.

Lee, P. 2004. Boreal Canada: state of the ecosystem, state of industry, emerging issues and projections. Report to the National Round Table on the Environment and the Economy. Global Forest Watch Canada, Edmonton, Alberta, Canada.

Lemelin, L. V., D. Bordage, M. Darveau, and C.
Lepage. 2004. Répartition de la sauvagine et d'autres oiseaux utilisant les milieux aquatiques en période de nidification dans le Québec forestier. Série de rapports techniques $\mathrm{N}^{\circ}$ 422. Service canadien de la faune, région du Québec, Environnement Canada, Sainte-Foy, Québec, Canada.

Longcore, J. R., D. G. McAuley, G. R. Hepp, and J. M. Rhymer. 2000. American Black Duck (Anas rubripes). In A. Poole and F. Gill, editors. The Birds of North America, Number 481. The birds of North America, Philadelphia, Pennsylvania, USA.

Maisonneuve, C., R. McNicoll,A. Desrosiers, and G. Lupien. 2002. Caractérisation de l'habitat de reproduction des canards arboricoles. Société de la faune et des parcs du Québec, Direction de la recherche sur la faune et Direction de l'aménagement de la faune du Saguenay, Lac SaintJean, Québec, Canada.

Malecki, R. A., and R. E. Trost. 1990. A breeding ground survey of Atlantic Flyway Canada Geese, Branta canadensis, in northern Quebec. The Canadian Field-Naturalist 104:575-578.

McIntyre, J. W. 1983. Nurseries: a consideration of habitat requirements during the early chickrearing period in Common Loons. Journal of Field Ornithology 54:247-253.

McIntyre, J. W., and J. F. Barr. 1997. Common Loon (Gavia immer). In A. Poole and F. Gill, editors. The birds of North America, Number 313. The Academy of Natural Sciences, Philadelphia, Pennsylvania, and The American Ornithologists' Union, Washington, D.C., USA.

Ménard, S., M. Darveau, and L. Imbeau. 2006. Forest inventory maps: A useful tool for a wetland habitat classification and regionalization in Quebec's forests. Eastern CANUSA Conference: 2006 conference handbook:105-110.

Mendall, H. L. 1958. The Ring-necked Duck in the northeast. University Press, Orono, Maine, USA.

Mowbray, T. 1999. American Widgeon (Anas americana). In A. Poole and F. Gill, editors. The birds of North America, Number 401. The birds of North America, Philadelphia, Pennsylvania, USA.

Mowbray, T. B., C. R. Ely, J. S. Sedinger, and R. 
E. Trost. 2002. Canada Goose (Branta canadensis). In A. Poole and F. Gill, editors. The birds of North America, Number 682. The birds of North America, Philadelphia, Pennsylvania, USA.

Ministère des Ressources naturelles du Québec (MRNQ). 2002. Rapport sur l'état des forêts québécoises 1995-1999. Available online at: http:// www.mrnfp.gouv.qc.ca/publications/forets/quebec/ Rapport-int.pdf.

North American Waterfowl Management Plan (NAWMP) Committee. 2004. North American waterfowl management plan 2004. Strategic guidance: strengthening the biological foundation. Canadian Wildlife Service, United States Fish and Wildlife Service, Secreteria de Medio Ambiente y Recursos Naturales de Mexico. Available online at: http://www.nawmp.ca/eng/neo e.html.

Newton, I. 1994. The role of nest sites in limiting the numbers of hole-nesting birds: a review. Biological Conservation 70:265-276.

Nichols, J. D. 1991. Science, population ecology, and the management of the American Black Duck. Journal of Wildlife Management 55:790-799.

Niemi, G., J. Hanowski, P. Helle, R. Howe, M. Münkkünen, L. Venier, and D. Welsh. 1998. Ecological sustainability of birds in boreal forests. Conservation Ecology 2:17.

Paquette, G. A., and C. D. Ankney. 1996. Wetland selection by American Green-winged Teal breeding in British Columbia. The Condor 98:27-33.

Pastor, J., S. Light, and L. Sovell. 1998. Sustainability and resilience in boreal regions: sources and consequences of variability. Conservation Ecology 2:16. [online] URL: http://www.consecol. org/vol2/iss2/art16/.

Patterson, J. H. 1976. The role of environmental heterogeneity in the regulation of duck populations. Journal of Wildlife Management 40:22-32.

Peterson, B., and G. Gauthier. 1985. Nest site use by cavity-nesting birds of the Cariboo Parkland, British Columbia. The Wilson Bulletin 97:319-331.

Pierre, J. P., H. Bears, and C. A. Paszkowski. 2001. Effects of forest harvesting on nest predation in cavity-nesting waterfowl. The Auk 118:224-230.
Pierre, J. P., and C.A. Paszkowski. 2000. Changes in aquatic bird densities after forest harvesting in boreal Alberta, Canada. Global Environmental Research 4:238-239.

Pöysä, H., and S. Pöysä. 2002. Nest-site limitation and density dependence of reproductive output in the common goldeneye Bucephala clangula: implications for the management of cavity-nesting birds. Journal of Applied Ecology 39:502-510.

Prince, H. H. 1968. Nest sites used by Wood Ducks and Common Goldeneyes in New Brunswick. Journal of Wildlife Management 32:489-500.

Ringelman, J. K., J. R. Longcore, and R. B. Owen, Jr. 1982. Breeding habitat selection and home range of radio-marked Black Ducks (Anas rubripes) in Maine. Canadian Journal of Zoology 60:241-248.

Robb, J. R., and T. A. Bookhout. 1995. Factors influencing Wood Duck use of natural cavities. Journal of Wildlife Management 59:372-383.

Robert, M., R. Benoit, and J. P. L. Savard. 1999. COSEWIC status report on the eastern population of the Barrow's Goldeneye (Bucephala islandica) in Canada. Committee on the Status of Endangered Wildlife in Canada, Ottawa, Ontario, Canada.

Robert, M., D. Bordage, J. P. L. Savard, G. Fitzgerald, and F. Morneau. 2000. The breeding range of the Barrow's Goldeneye in eastern North America. The Wilson Bulletin 112:1-7.

Rusch, D. H., C. D. Ankney, H. Boyd, J. R. Longcore, F. Montalbano, III, J. K. Ringelman, and V. D. Stotts. 1989. Population ecology and harvest of the American Black Duck: a review. Wildlife Society Bulletin 17:379-406.

SAS Institute Inc. 2002. SAS for Windows computer program, version 9.1. By SAS Institute Inc., Cary, North Carolina, USA.

Savard, J. P. L. 1988. Use of nest boxes by Barrow's Goldeneyes: nesting success and effect on the breeding population. Wildlife Society Bulletin 16:125-132.

Savard, J. P. L., and M. Robert. 2007. Use of nest boxes by Goldeneyes in eastern North America. The 
Wilson Journal of Ornithology 119:28-34.

Savard, J. P. L., D. Bordage, and A. Reed. 1998. Surf Scoter (Melanitta perspicillata). In A. Poole and F. Gill, editors. The birds of North America, Number 363. The birds of North America, Philadelphia, Pennsylvania, USA.

Schmiegelow, F. K. A., C. S. Machtans, and S. J. Hannon. 1997. Are boreal birds resilient to forest fragmentation? An experimental study of shortterm community responses. Ecology 78:1914-1932.

Scrimgeour, G. J., W. M. Tonn, C.A. Paszkowski, and P. M. K. Aku. 2000. Evaluating the effects of forest harvesting on littoral benthic communities within a natural disturbance-based management model. Forest Ecology and Management 126:77-86.

Sénéchal, H. 2003. étude comparative de l'écologie de nidification et d'élevage des couvées de Garrot à aeil d'or (Bucephala clangula) et de Harle couronné (Lophodytes cucullatus) dans un habitat de rivière.. Université Laval, Sainte-Foy, Québec, Canada.

Stotts, V. D., and D. E. Davis. 1960. The Black Duck in the Cheasapeake Bay of Maryland: breeding behavior and biology. Cheasapeake Science 1:127-154.

Walker, B. 1995. Conserving biological diversity through ecosystem resilience. Conservation Biology 9:747-752.

Walker, B., C. S. Holling, S. R. Carpenter, and A. Kinzig. 2004. Resilience, adaptability and transformability in social-ecological systems. Ecology and Society 9:5. 